\title{
Choctaw Language
}

National Cancer Institute

\section{Source}

National Cancer Institute. Choctaw Language. NCI Thesaurus. Code C153881.

A Native American language, traditionally spoken by the Native American Choctaw people of the southeastern United States. 